\title{
KERUKUNAN DALAM KEANEKARAGAMAN: Struktur Keberagamaan Masyarakat Pucakwangi
}

\author{
Mas'udi \\ Institut Agama Islam Negeri Kudus - Indonesia \\ e-mail: masudijufri@stainkudus.ac.id
}

\begin{abstract}
This study aims to determine the religious structure of the community of Pucakwangi Village, Pucakwangi District, Pati Regency, Central Java Province. Religious awareness is an important foundation for the formation of religious harmony in diversity. With a qualitative functional structural approach, this study analyzes the structures that form community harmony in its diversity. The results of the study show some basic structures found in the midst of the diversity of the Pucakwangi Village community. Building an attitude of sympathy among followers of religion created with the participation of Christians in "tahlilan" activities, visiting each other in commemoration of religious holidays is another part of the forms of harmony they build together. Counteracting religious radicalism is another aspect of harmony that is built by the community with an awareness of the interrelationships of their recent lives with their ancestors.
\end{abstract}

\begin{abstract}
Abstrak: Penelitian ini bertujuan untuk mengetahui struktur keberagamaan masyarakat Desa Pucakwangi Kecamatan Pucakwangi Kabupaten Pati Provinsi Jawa Tengah. Kesadaran beragama merupakan pondasi penting terbentuknya kerukunan beragama dalam keanekaragaman. Dengan pendekatan kualitatif fungsional struktural, kajian ini menganalisis struktur-struktur yang membentuk kerukunan masyarakat dalam keanekaragamannya. Hasil penelitian menunjukkan beberapa struktur pokok yang terdapat di tengah-tengah keberagamaan masyarakat Desa Pucakwangi. Membangun sikap simpati di antara para pemeluk agama tercipta dengan partisipasi para pemeluk agama Kristen pada kegiatan tahlilan, saling berkunjung di peringatan hari-hari besar agama adalah bagian lain bentuk-bentuk kerukunan yang mereka bangun bersama. Menangkal radikalisme beragama merupakan aspek kerukunan lain yang dibangun oleh masyarakat dengan kesadaran terhadap interkorelasi kehidupan mereka terkini dengan para leluhur.
\end{abstract}

Keywords: harmony; diversity; radicalism; inter-correlation; kinship

\section{A. Pendahuluan}

Kajian tentang kerukunan di tengah-tengah kehidupan masyarakat yang multietnik merupakan sebuah pijakan pokok untuk mengurai aspek-aspek interaksi yang terjalin di antara mereka. Kerukunan merupakan modal berharga 
yang harus selalu dijaga dan dilestarikan. Hidup rukun dalam lingkup kehidupan sosial yang multi etnik merupakan cita-cita luhur yang selalu didambakan oleh seluruh masyarakat. Perjuangan yang dibangun oleh para tokoh kemerdekaan Indonesia, kesatuan hidup dalam bangunan kekeluargaan merupakan semangat, atau nilai yang menjadi dasar dalam hubungan sosial di antara sesama anak bangsa. ${ }^{1}$ Kenyataan atas kesatuan dalam keanekaragaman ini meneguhkan bahwa negara Indonesia dibangun di atas aneka ragam suku, budaya, agama, etnik, dan bahasa. ${ }^{2}$

Membangun kerukunan dalam kehidupan masyarakat yang multikultural, memerlukan kesepahaman di antara subkultur masyarakat yang terdapat di dalamnya. Pada situasi ini, penting menyadari perlunya membangun kesadaran sikap tradisional dengan upaya saling membangun keterikatan antara satu subkultur masyarakat dengan lainnya. ${ }^{3}$ Kondisi ini secara mendasar meneguhkan bahwa penciri dalam kerukunan masyarakat multikultur adalah munculnya sikap kekeluargaan, kolektivisme, atau komunalisme sebagaimana hal ini menjadi penciri dari masyarakat tradisional. ${ }^{4}$

Dinamika kerukunan dalam masyarakat tradisional Indonesia menghadapi polemik yang cukup memprihatinkan di era revolusi. Perseteruan antara kaum Nasionalis, Islam, dan Partai Komunis Indonesia (PKI) di sisi yang lain, hal tersebut telah menimbulkan retaknya hubungan kerukunan dalam kebhinnekaan. ${ }^{5}$ Polemik yang terjadi di antara elemen-elemen bangsa dari terkait adanya Gerakan 30 September 1965 Partai Komunis Indonesia atau yang lebih dikenal dengan G/30/S/PKI. Gerakan ini telah menumbuhkan kebencian yang berlarutlarut sehingga komunikasi sosial di masyarakat menjadi terganggu dan berujung kebencian. ${ }^{6}$

${ }_{1}^{1}$ Amri Marzali, Antropologi dan Pembangunan (Jakarta: Kencana, 2015), 168.

${ }^{2}$ Irene Ludji dan Mariska Lauterboom, "Learning from the Socio-Religious Integration in Solor Village Indonesia," Analisa: Journal of Social Science and Religion 22, no. 1 (2015): 43-56, https://doi.org/10.18784/analisa.v22i1.145. 165.

${ }^{3}$ Irwan Abdullah, Konstruksi dan Reproduksi Kebudayaan (Yogyakarta: Pustaka Pelajar, 2015),

${ }^{4}$ Marzali, Antropologi dan Pembangunan, 170.

5Bambang Pranowo, Memahami Islam Jawa (Jakarta: Pustaka Alvabet, 2011), 2.

6Merle Calvin Ricklefs, Sejarah Indonesia Modern 1200-2004, terj. Satrio Wahono (Jakarta: Serambi Ilmu Semesta, 2005), 556. 
Dampak G/30/S/PKI bagi hubungan kehidupan sosial kemasyarakatan di Indonesia sangat kental terasa. Masyarakat terjerat dalam jaman poyok-poyokan atau era saling mengejek untuk menggambarkan dampak politik yang diterapkan oleh Partai Komunis Indonesia (PKI). ${ }^{7}$ Situasi sosial tergambar di atas telah menimbulkan adanya friksi-friksi sosial di masyarakat yang tampak terasa di ranah-ranah masyarakat kelas bawah sekalipun. Keadaan ini pula tampak terlihat dalam kehidupan masyarakat Desa Pucakwangi Kecamatan Pucakwangi Kabupaten Pati Provinsi Jawa Tengah.

Masyarakat ing mriki nate mengalami konflik sing diakibatke oleh kejadian PKI. Kejadian niku sekitar tahun 1971. Saling curiga masyarakat niku pernah dados situasi ingkang umum masyarakat adepi. (Masyarakat sini pernah mengalami konflik yang diakibatkan oleh adanya kejadian PKI. Kejadiannya sekitar tahun 1971. Saling curiga di antara masyarakat pernah menjadi kejadian-kejadian umum yang terjadi di masyarakat). ${ }^{8}$

Upaya untuk mewujudkan kerukunan dalam keanekaragaman masyarakat Desa Pucakwangi mengalami pertentangan sosial yang cukup panjang. Samsuri selaku Sekretaris Desa Pucakwangi menjelaskan bahwa di tahun 1971 masyarakat dihadapkan dengan kecurigaan-kecurigaan yang diakibatkan oleh berhembusnya informasi sisa-sisa pengikut Partai Komunis Indonesia (PKI). Hal ini memicu timbulnya keretakan-keretakan sosial di masyarakat. Namun, seiring dengan munculnya para pendatang baru dan peran mereka di masyarakat, sedikit demi sedikit, ketegangan yang ada mulai bisa diurai dan dihapuskan.

Masyarakat generasi sisa-sisa pengikut Partai Komunis Indonesia (PKI) di Desa Pucakwangi banyak beralih keyakinan menjadi pengikut agama Kristen. Samsuri menjelaskan:

Rata-rata pengikut PKI niku mas akhire sami nderek dados Nasrani. Pak Sardu suaminipun Yu Satina niku Kristen eks PKI. (Rata-rata pengikut PKI, akhirnya kebanyakan dari mereka memeluk agama Nasrani. Pak Sardu suami Mbak Satina itu Kristen dan eks PKI). ${ }^{9}$

Gesekan yang terjadi dalam kehidupan keagamaan masyarakat Desa Pucakwangi ini akhirnya melebur dalam kesatuan sikap bersama untuk mem-

7Pranowo, Memahami Islam Jawa, 311.

8Wawancara dengan Samsuri, SH, Sekretaris Desa Pucakwangi, 15 Januari 2017.

${ }^{9}$ Wawancara dengan Samsuri, SH, Sekretaris Desa Pucakwangi, 15 Januari 2017.

JURNAL THEOLOGIA — Volume 29, Nomor 2, Desember 2018 
bangun struktur sosial masyarakat yang lebih majemuk. Masing-masing dari mereka bertahap menyadari terbentuknya sikap-sikap sakral dan profan dalam keberagamaan masing-masing. Dalam konteks ini, dipahami bahwa tidak ada satu pun aktivitas manusia yang terlepas dari keyakinan teologisnya, termasuk hubungan antar penganut agama yang berbeda. Dasar-dasar hubungan kemanusiaan menjadi titik pijak yang harus disadari oleh para pemeluk agama, karena secara normatif timbulnya kesadaran terhadap kesatuan ciptaan, hal tersebut dapat menjadi modal berharga timbulnya harmonisasi di masyarakat.10

Hubungan sosial keagamaan masyarakat Desa Pucakwangi bertitik-pijak kepada hubungan antar pemeluk agama dalam suasana sosial yang kompleks dan hal tersebut ditandai dengan progres dan kebersamaan.11 Johan Galtung menjelaskan pentingnya pemahaman tentang tantangan dan peluang yang ditawarkan dalam ruang-ruang sosial di masyarakat. ${ }^{12}$ Ada beberapa penelitian sebelumnya tentang kondisi sosiologis masyarakat Pati. Suharko dalam penelitiannya mengungakapkan peluang-peluang yang bisa dikreasikan dalam membangun harmoni di masyarakat Pati. Suharko melihat pertumbuhan sosial keagamaan di Kabupaten Pati yang cukup sensitif mengingat pertumbuhan ekonomi dari jalur eksplorasi kawasan karst yang terdapat di latar wilayah Pati bagian Selatan. ${ }^{13}$ Aset untuk pengolahan semen di kawasan ini juga sensitif menimbulkan konflik. Munculnya friksionalitas yang berujung kepada konflik kepentingan di masyarakat juga tidak bisa dilepaskan dari kondisi-kondisi masa lalu masyarakat yang kemudian lambat-laun muncul kembali masa-masa kini kehidupan mereka. Sebagian terungkap sebab-sebab kemunculan konflik tersebut dalam analisis Munawir Aziz karena kuasa kolonial Belanda di masa-masa lampau. ${ }^{14}$

10Syahrin Harahap, Teologi Kerukunan (Jakarta: Prenadamedia Group, 2011), 16.

11M. Amin Abdullah, "An Analytical Perspective in the Study of Religious Diversity: Searching for a New Model of the Philosophy of the Study of Religions," in Religious Harmony, ed. Michael Pye (Berlin: Walter de Gruyter, 2006), 54.

12Johan Galtung, Peace by Peaceful Means Peace and Conflict, Development and Civilization (London: Sage Publications, 1996), 3.

13Suharko, "Karst: Ditambang atau Dilestarikan, Konflik Sosial Rencana Pembangunan Pabrik Semen di Kabupaten Pati Jawa Tengah," Jurnal Ilmu Sosial dan Ilmu Politik 17, no. 2 (2013): 163-79, https://doi.org/10.22146/JSP.10881.

14Munawir Aziz, "Identitas Kaum Samin Pasca Kolonia Pergulatan Negara, Agama, dan Adat dalam Pro-Kontra Pembangunan Pabrik Semen di Sukolilo, Pati, Jawa Tengah," Jurnal Kawistara 2, no. 3 (2012): 252-63, https://doi.org/10.22146/kawistara.3937. 
Berdasar kepada analisis kajian pertumbuhan sosial di wilayah Pati oleh dua peneliti tersebut, kenyataannya masih berkutat pada penjelasan polemik wilayah dengan persinggugannya atas masyarakat luar. Hal ini menjadi cukup kontras dengan dinamika kehidupan sosial masyarakat Desa Pucakwangi Kecamatan Pucakwangi Kabupaten Pati Jawa Tengah yang mempolarisasikan kerukunan dalam keanekaragaman agama internal mereka. Keanekaragaman sosial yang terdapat di tengah-tengah masyarakat tidak menjadi sebuah penghalang yang membatasi terjalinannya kerukunan dan harmoni dalam jaringannya dengan masyarakat di lini manapun. Aneka ragam agama dan keyakinan yang tumbuh di masyarakat berjalan di koridor keagamaan masing-masing tanpa terjadi disintegrasi. Kebebasan untuk menjalankan rutinitas keagamaan dan keyakinan senantiasa dijaga bersama sehingga keutuhan sosial yang dimiliki utuh dalam keberadaannya.

Keterbukaan sosial yang tercipta di tengah-tengah kehidupan masyarakat Desa Pucakwangi menjadi dasar analisis yang terumuskan dalam kajian ini. Secara terstruktur kajian ini difokuskan kepada analisis tentang apakah dasardasar keberagamaan yang terbentuk di tengah-tengah masyarakat? Analisis selanjutnya diarahkan kepada penjelasan tentang pola-pola kerukunan yang mereka bangun menyiasati keanekaragaman yang berjalan. Pada bagian akhir kajian ini mempertanyakan apakah formulasi sosial yang mereka bangun demi melestarikan kerukunan dalam keanekaragaman yang berjalan?

Pendekatan yang digunakan dalam penelitian ini adalah pendekatan sosialbudaya. Merunut kepada penjelasan Mudjahirin Thohir bahwa peristiwa yang muncul di permukaan dicoba dipahami berdasarkan pada konstruksi kognitif masyarakat yang bersangkutan. Karena itu, perspektif yang digunakan adalah perspektif emik. ${ }^{15}$

Fenomena kerukunan dalam keanekaragaman masyarakat Desa Pucakwangi Kecamatan Pucakwangi Kabupaten Pati Jawa Tengah dianalisis secara kualitatif. Berawal dari penelitian yang dilakukan penulis dimulai tahun 2016 sampai akhir 2017, data lapangan yang terkumpul menginformasikan struktur keberagamaan masyarakat yang utuh dalam melestarikan persatuan dan kesatuan sosial di antara mereka. Persentuhan keyakinan yang terdapat di 2005), 23.

15Mudjahirin Thohir, Kekerasan Sosial di Pesisir Utara Jawa (Semarang: Lengkong Cilik Press, 
tengah-tengah masyarakat menunjukkan kedewasaan mereka untuk saling menghormati perbedaan yang berjalan dan melingkupi kehidupan sehari-hari.

Data-data yang digunakan untuk analisis kajian kerukunan dalam keanekaragaman pada penelitian ini, didasarkan pada data-data lapangan. Dalam pengumpulan data lapangan, peneliti turun ke lapangan sendiri dengan wawancara, observasi dan dokumentasi. Hasil pengumpulan data diolah secara kualitatif. Untuk selanjutnya, metode pengumpulan data dilakukan dengan observasi, wawancara, dan dokumentasi.

Metode kerja penelitian ini dirancang melalui penjelasan tentang strukturstruktur yang terbentuk di masyarakat Desa Pucakwangi dalam kerangka terbentuknya kerukunan dalam keanekaragaman di antara mereka. Untuk selanjutnya, struktur-struktur pembentuk kerukunan terbentuk dirumuskan fungsi-fungsi sosial yang diakibatkannya, sehingga teori fungsional-struktural dalam kerangka analisis Bronislaw Malinowski, Mujiyono Abdillah, dan Nur Syam menjadi pijakan teoritis dalam kajian ini.

Bersandar kepada pendekatan sosial-budaya atas analisis kerukunan dalam keanekaragaman kehidupan beragama masyarakat Desa Pucakwangi, asas teoritis yang dibangun oleh Bronislaw Malinowski ${ }^{16}$ menjadi sebuah jembatan bahwa dalam terbentuknya kehidupan di masyarakat disinkronisasikan bersandar kepada dasar pertukaran dari hal-hal yang terbentuk secara terstrukur.

Sementara itu, Mujiyono Abdillah menegaskan bahwa realitas sosial terbentuk bersandar kepada jaringan-jaringan abstrak yang terdiri dari berbagai komponen struktural. ${ }^{17}$ Secara seksama pula dapat dimaknai bahwa terbentuknya kerukunan dalam keanekaragaman masyarakat Desa Pucakwangi disandarkan kepada terciptanya struktur sosial dan kebudayaan yang dimiliki masyarakat.

Pada bagian yang lain, terbentuknya dasar kerukunan masyarakat yang diciptakan oleh hubungan kebudayaan, analisis struktural-fungsional Nur Syam menjadi dasar pijakan dengan penjelasannya bahwa kebudayaan sebagai

16Koentjaraningrat, Sejarah Teori Antropologi I (Jakarta: UI-Press, 2007), 160-64.

${ }^{17}$ Mujiyono Abdillah, Islam Dialektik: Varitas Islam Terkini (Semarang: al-Hikmah, 2013), 106. 
sebuah proses keterkaitan pengaruh satu subsistem atas subsistem lainnya.18 Terbentuknya keanekaragaman dalam keberagamaan masyarakat Desa Pucakwangi juga dapat dilihat dari pertemuan-pertemuan sub-sub kebudayaan yang berkembang di tengah-tengah masyarakat.

\section{B. Dasar Keberagamaan Masyarakat}

Desa Pucakwangi merupakan salah satu wilayah di Kabupaten Pati dengan luas wilayah 895.623 hektar. Luas persawahan mencakup 613.030 hektar, luas pekarangan 221.030 hektar, dan luas tegal mencakup hutan rakyat 9.000 hektar. Berjarak 30 kilometer dari ibukota kabupaten. Desa Pucakwangi terletak di sebelah selatan Ibu Kota Pucakwangi dengan batas-batas, sebelah Utara berbatasan dengan Desa Pelemgede, sebelah Timur berbatasan dengan Desa Mencon, sebelah Selatan berbatasan dengan Kabupaten Mojoagung, dan sebelah Barat berbatasan dengan Desa Tanjung Sekar. ${ }^{19}$

Keberagamaan masyarakat Desa Pucakwangi tampak beraneka ragam. Kehidupan masyarakat dihiasi dengan tenggang rasa dan saling menghormati antara satu pemeluk agama dengan agama yang lain. Budaya gotong royong sangat dijunjung tinggi. Perwujudan rasa ini banyak dihadirkan oleh masyarakat di saat mereka menghadapi musim tanam dan musim panen pertanian. Aktivitas pertanian menjadi salah satu bagian kegotong-royongan masyarakat yang lestari di perjalanan kehidupan kebhinnekaan masyarakat. Kebhinnekaan hidup masyarakat tampak kuat dari besaran populasi masyarakat Muslim yang berjumlah 5511 jiwa bersinergi kuat dengan minoritas masyarakat Kristiani yang berjumlah 31 jiwa. ${ }^{20}$

Dimensi-dimensi kerukunan dalam kehidupan masyarakat Desa Pucakwangi tampak sinergis pada hubungan internal Muslim sebagai penduduk mayoritas. Gambaran masyarakat santri sebagai pengikut organisasi masyarakat Nahdlatul Ulama (NU) dan organisasi masyarakat Muhammadiyah (MD), kedua organisasi ini berjalan beriringan mengisi ruang-ruang keagamaan internal kehidupan mereka. Penjelasan ini sebagaimana disampaikan oleh Muhammad Ma'ruf dengan penegasannya bahwa mayoritas masyarakat Desa Pucak-

18Nur Syam, Madzhab-madzhab Antropologi (Yogyakarta: LKiS, 2012), 29.

${ }^{19}$ Buku Monografi Desa Keadaan pada Bulan September Tahun 2015.

${ }^{20}$ Observasi lapangan bersama Samsuri. SH, Sekretaris Desa Pucakwangi, 15 Januari 2017. 
wangi adalah pengikut Nahdlatul Ulama (NU). Sebagian lain dari masyarakat desa tersebut adalah pengikut Muhammadiyah (MD).21

Kesatuan pemeluk agama dalam kesamaan pemahaman menurut Koentjaraningrat tercipta oleh munculnya kesamaan emosi keagamaan. Koentjaraningrat menyatakan bahwa pada awal keberadaannya di bumi, manusia mengembangkan religi karena adanya getaran jiwa, yaitu emosi keagamaan yang timbul dalam jiwa karena adanya emosi terhadap keagamaan tersebut, dan bukan karena manusia membayangkan adanya ruh yang abstrak, berupa kekuatan yang menyebabkan hidup dan gerak dalam alam semesta. ${ }^{22}$ Kerangka dasar keagamaan ini terangkum dalam kesatuan para pemeluk agama menginterpretasi hakikat sakral dan profan dalam kehidupan. Dua ranah kehidupan, yang satu berdimensi duniawi dan yang kedua berdimensi ukhrawi. ${ }^{23}$

Pola keagamaan masyarakat Muslim Desa Pucakwangi tergolong santri. Intensitas kegiatan pengajian di tengah-tengah masyarakat menjadi sesuatu yang tampak umum dilaksanakan. Kegiatan-kegiatan keagamaan ini banyak dilaksanakan di masjid-masjid, mushola, dan majlis-majlis ta'lim dengan intensitas waktu yang hampir berkelanjutan di setiap malamnya. Kegiatan keagamaan yang dilangsungkan oleh para remaja masjid menjadi pemandangan umum yang dapat disaksikan di tengah-tengah kehidupan masyarakat. Kondisi keagamaan ini juga dapat dilihat dari hubungan sosial kemasyarakatan dalam lintasan sosial yang berjalan di antara masyarakat. Sikap empati antar pemeluk agama tampak hadir dari pola hubungan sosial yang berjalan di masyarakat. Pada peringatan hari-hari besar keagamaan, masing-masing pemeluk agama di Desa Pucakwangi saling mengunjungi sebagai ekspresi kebahagiaan atas perayaan keagamaan yang berlangsung di masing-masing pemeluk agama. ${ }^{24}$

Kesatuan sikap keagamaan dari perbedaan keyakinan masyarakat Desa Pucakwangi tertata dengan baik sebagai modal kerukunan di tengah-tengah mereka. Pebedaan budaya yang terdapat di tengah mereka dipandang sebagai

\footnotetext{
21Wawancara dengan Muhammad Ma'ruf, warga Desa Pucakwangi, 21 Januari 2018.

${ }^{22}$ Koentjaraningrat, Pengantar Antropologi II: Pokok-pokok Etnografi (Jakarta: Rineka Cipta, 2005), 198.

23Suwardi Endraswara, Agama Jawa: Ajaran, Amalan, dan Asal-usul Kejawen (Yogyakarta: Narasi, 2015), 17.

24Wawancara dengan Muhammad Ma'ruf, warga Desa Pucakwangi, 21 Januari 2018.
} 
potensi (anugerah/maslahat), bukan sebagai kerugian (madharat), dengan memadukan, meramu, dan mengembangkannya sesuai dengan tuntutan dan perubahan sosial, sehingga menjadi kekuatan dan penguatan kemasyarakatan. Masyarakat Desa Pucakwangi menempuh jalan penerimaan dan penghormatan terhadap perbedaan yang ada di tengah-tengah sosialnya dengan mencari titik temu kesamaan sebagai identitas sosial. ${ }^{25}$ Ciri masyarakat yang demikian ini adalah ciri masyarakat madani, dengan salah satu model sosial mereka demokratisasi. Masyarakat demokratis adalah masyarakat yang dalam ciri kulturalnya menunjukkan bahwa warga memiliki kesadaran terhadap keberagaman dan karena itu cara hidup yang dinilai beradab adalah menghargai perbedaan sekaligus mengupayakan mencari titik temu yang memungkinkan untuk kepentingan itu baru memungkinkan kalau didukung oleh faktor-faktor lain, seperti keteraturan hukum serta keadilan sosial ekonomi dan politik.26

Mewujudkan keteraturan hukum dan keadilan sosial dalam masyarakat menjadi titik tolak berharga guna menciptakan kerukunan dalam keanekaragaman. Secara terstruktur kondisi serupa sebagai bagian dari ciri pertahanan masyarakat yang majemuk. Seperti layaknya tubuh yang memiliki struktur yang dapat dikenali (jantung, otak, kulit, kaki, hati), begitu juga dengan masyarakat yang memiliki struktur-struktur seperti ekonomi, sistem politik, sistem hukum, keluarga, dan agama. Lebih lanjut, survivalitas masyarakat diilustrasikan layaknya tubuh yang memiliki struktur dengan fungsi-fungsi yang jelas (jantung untuk memompa darah, otak untuk menyelaraskan tindakan dan memberikan kecerdasan, hati untuk membersihkan tubuh), begitu juga masyarakat yang memiliki struktur-struktur fungsional-ekonomi membantu masyarakat menata penghasilan dan beradaptasi dengan lingkungan, politik membantu masyarakat mencapai tujuan, komunitas membantu menyosialisasikan dan memadukan unsur-unsur yang berbeda, dan hukum mengatur serta mengendalikan masyarakat. ${ }^{27}$ Tatanan sosial inilah sebagai penggambaran dasar yang dilakukan para

25Wawancara dengan Samsuri SH, Sekretaris Desa Pucakwangi, 15 Januari 2017.

${ }^{26}$ Mudjahirin Thohir, Multikulturalisme Agama, Budaya, dan Sastra (Semarang: Gigih Pustaka Mandiri, 2013), 42-3.

27Ken Plummer, Sociology The Basic, terj. Nanang Martono dan Sisworo OJakarta: Rajawali Press, 2013), 43-4.

JURNAL THEOLOGIA — Volume 29, Nomor 2, Desember 2018 
pemangku kebijakan Desa Pucakwangi dengan membangun kesetaraan sosial guna meneguhkan keberlanjutan dalam kebersamaan. ${ }^{28}$

Menjaga kehidupan masyarakat yang beraneka ragam adalah usaha besar yang selalu dilakukan oleh para pemangku kebijakan di tingkat Desa Pucakwangi. Penanaman sikap pluralitas dalam kebhinnekaan yang ada merupakan agenda-agenda mendasar yang dilakukan oleh para aparat desa sehingga mereka dapat meminimalisir terjadinya konflik di masyarakat. Dinamika sosial yang berjalan di antara masyarakat dijelaskan sebagai sebuah pondasi bahwa mereka diciptakan oleh Tuhan dalam berbacam macam bentuk warna, agama, ras, dan budaya. Berbagai upaya menyadarkan masyarakat ini menimbulkan semakin tumbuhnya sikap empati di tengah-tengah kehidupan keberagamaan masyarakat Desa Pucakwangi. Kebaikan hubungan yang terjalin antara Muslim dan kristiani tampak terlihat ketika saudara mereka mengalami kesusahan. Dalam musibah kematian yang menimpa salah seorang warga, masing-masing dari mereka datang untuk menyampaikan belasungkawa atas musibah yang menimpa sesamanya. Tradisi berkirim beras perwujudan belasungkawa meringankan beban saudaranya yang tertimpa musibah, umum terlihat di kehidupan masyarakat Desa Pucakwangi. ${ }^{29}$

\section{Kesadaran Saling Memiliki}

Pembentukan kerukunan dalam keanekaragaman sosial di masyarakat tidaklah terbentuk secara instan. Persinggungan dengan dinamika konflik antar elemen dalam suatu masyarakat niscaya dijumpai karena dasar kebhinnekaan itu sendiri adalah ketidakseragaman sosial. Ditinjau dari sudut pandang teori evolusi, masyarakat senantiasa menjumpai perubahan. Sebuah spesies meng-

\footnotetext{
28Pemerataan sosial di masyarakat Desa Pucakwangi tampak terlihat dari penempatan bantuan-bantuan kepada lembaga-lembaga keagamaan yang ada di masyarakat. Sebagaimana tertuang dalam Surat Permohonan Pencairan Bantuan Keuangan Kepala Desa untuk Lembaga Keagamaan Tahun Anggaran 2016, semua lembaga keagamaan yang ada mendapat jatah tersebut. Keseluruhan bantuan tersebut diberikan kepada dua puluh lima masjid-masjid dan musholamushola sarana tempat beribadah kaum muslim dan satu bantuan dialokasikan kepada gereja tempat beribadah umat kristiani. Total bantuan yang ada di tahun anggaran 2016 adalah dua puluh enam. Lihat: Surat Pernyataan Pertanggung Jawaban Bantuan Keuangan kepada Desa untuk Fasilitasi Lembaga Keagamaan di Kabupaten Pati Tahun Anggaran 2016, tertuang dalam SK Bupati Pati Nomor: 900/1290/2016, tanggal 30 April 2016.
}

${ }^{29}$ Wawancara dengan Muhammad Ma'ruf, warga Desa Pucakwangi, 21 Januari 2018. 
ubah diri dari suatu kondisi kepada kondisi yang lain guna menjejak kepada lingkungan yang lebih baik. ${ }^{30}$ Herbert Spencer menyatakan bahwa sebab utama terjadinya perubahan adalah perhatian terhadap kesatuan (unity) dan dualitas (duality) atas aksi masing-masing. ${ }^{31}$ Konsep kesatuan yang disampaikan oleh Spencer di atas terikat kuat pada kesadaran masyarakat Desa Pucakwangi bahwa mereka merupakan penanggung jawab utama terciptanya kerukunan dalam keanekaragaman yang dibangun. Untuk itulah, kesadaran terhadap dualitas yang juga terbentuk dalam kehidupan sosial yang beranekaragam tersebut tampak terlihat dari usaha masyarakat saling menghormati antara satu pemeluk agama dengan pemeluk agama yang lain. Aktivitas ini tampak praktik pelaksanaannya di peringatan hari-hari besar keagamaan. Pada Idul Fitri atau Idul Adha, masyarakat Kristiani ikut berpartisipasi dalam melakukan penghormatan kepada kaum Muslim dengan berkunjung ke rumah mereka. Begitu pula sebaliknya, masyarakat kristiani tersebut menyiapkan aneka macam jajan di rumah mereka sebagai penghormatan atas kunjungan yang dilakukan oleh saudara-saudara mereka yang beragama Islam. ${ }^{32}$

Fenomena keberagamaan masyarakat Desa Pucakwangi memperjelas bahwa memahami setiap unsur bangunan masyarakat menjadi hal pokok yang harus diperhatikan agar masing-masing mampu bersandar kepada kesadaran antara satu unsur dengan unsur yang lain, mustahil berjalan sendiri-sendiri. Tentu saja, dalam pertumbuhan masyarakat itu sendiri, setiap individu akan dipertemukan dengan strata-strata sosial yang kenyataannya juga seringkali dimunculkan guna mengamati tingkat variasi dalam masyarakat. Peter Burke menyatakan bahwa struktur sosial yang terjadi di masyarakat akan berjalan di antara hierarki yang terjadi di tengah-tengah mereka. Hierarki sosial tradisional didasarkan pada kelahiran ascription dan mobilitas sosialnya rendah. Sebaliknya, hierarki modern didasarkan pada merit prestasi dan mobilitas sosialnya tinggi. Sebuah masyarakat estates (sistem tuan tanah, lord) telah digantikan oleh masyarakat yang terdiri atas kelas-kelas, yang memiliki kesempatan yang setara. Selain itu, dalam masyarakat tradisional, unit dasarnya adalah kelompok kecil

30Wendy Northcutt, The Darwin Awards Survival of the Fittest (New York: The Dutton Publishing Group, 2001), 11.

${ }^{31}$ Herbert Spencer, First Principles (New York: Cambridge University Press, 2009), 286.

32Wawancara dengan Muhammad Ma'ruf, warga Desa Pucakwangi, 21 Januari 2018. 
yang di dalamnya saling kenal, atau disebut komunitas gemeinschaft. Namun, setelah adanya konsep modernisasi, inti dasarnya adalah masyarakat luas yang impersonal gesellschaft. 33

Kemunculan hierarki sosial yang terjadi di masyarakat memang tidak bisa dijauhkan dari dinamika perubahan masyarakat itu sendiri. Dalam hal ini Pip Jones mencoba menengahi bahwa pengaruh terpenting terhadap kehidupan sosial adalah distribusi keberuntungan dan dampaknya pada perilaku. Apabila keberuntungan itu tersebar secara tidak merata, kesempatan orang-orang yang beruntung untuk memilih bagaimana berperilaku jauh lebih besar daripada orang-orang yang tidak beruntung. ${ }^{34}$ Dimensi ruang dan waktu sebuah peristiwa menjadi sangat terkait dengan nilai-nilai keberuntungan atau sebaliknya. Sebagai gagasan atas kenyataan ini penting dicatat bahwa terjadinya perubahan sosial sangat terkait atas kondisi yang melingkupi. ${ }^{35}$ Seperti halnya, susunan golongan satu kota ditentukan oleh fungsi ekonominya, dan jika satu kota dikuasai satu industri, keperluan teknis industri tersebut akan benar-benar mempengaruhi struktur sosialnya. ${ }^{36}$

Kerukunan masyarakat Desa Pucakwangi juga tidak dapat dilepaskan dari munculnya dinamika sosial kemasyarakatan yang berjalan di masa lampau. Hierarki kuasa ekonomi di masyarakat tampak terjadi sebelum pencapaian harmoni sosial masyarakat di masa kini. Kondisi ini sangat terkait dengan situasi sosial yang sedang berselisih kuasa antara masyarakat pribumi dengan Cina yang hadir mengisi ruang perekonomian masyarakat. Meskipun dalam perjalanannya perseteruan antara masyarakat pribumi dengan Cina pendatang tidak terjadi secara terang-terangan, namun kompetisi di antara mereka dalam perebutan ekonomi masyarakat sangat kuat aroma persaingannya. Fenomena ini banyak terjadi dalam kepemilikan toko-toko bahan bangunan yang ada di masyarakat. ${ }^{37}$

33Peter Burke, Sejarah dan Teori Sosial (Jakarta: Yayasan Pustaka Obor Indonesia, 2015), 214.

${ }^{34}$ Pip Jones, Pengantar Teori-teori Sosial dari Teori Fungsionalisme hingga Post-Modernisme, terj. Ahmad Fedyani Saifuddin (Jakarta: Yayasan Obor Indonesia, 2009), 13.

${ }^{35}$ Nanang Martono, Sosiologi Perubahan Sosial Perspektif Klasik, Modern, Posmodern, dan Poskolonial (Jakarta: Rajawali Pers, 2014), 3.

36Lance Castles, Tingkah Laku Agama, Politik dan Ekonomi di Jawa: Industri Rokok di Kudus, terj. J. Sirait (Jakarta: Sinar Harapan, 1982), 87.

37Wawancara dengan H. Mukhlisin, Modin Desa Pucakwangi, 15 Januari 2017. 
Dinamika sosial ekonomi yang berjalan di tengah-tengah masyarakat Desa Pucakwangi menunjukkan bahwa kerukunan di masyarakat juga selalu diiringi dengan percikan konflik. Tetapi konflik yang terjadi dalam proses demokrasi harus mengikuti hukum atau aturan main yang adil dan beradab. Ketaatan atau kepatuhan pada hukum yang berlaku adalah salah satu syarat mutlak bagi keberlakuan demokrasi dalam kehidupan masyarakat. Tanpa ketaatan pada hukum, yang ada dalah kerumunan dan kekacauan, di mana setiap pihak atau kekuatan berlaku sewenang-wenang. Jadi melalui hukum itulah kebudayaan dan peradaban seperti perikemanusiaan, termasuk keterwujudan kesetaraan derajat individu demi kesejahteraan bersama, dapat ditegakkan. ${ }^{38}$

Pertemuan demi pertemuan dalam lingkaran kehidupan keberagamaan dan keagamaan mustahil dihindari. Setiap orang akan berjumpa dengan orang lain tanpa mereka pilih latar belakang agama, budaya, ras, dan kultur sosial yang mereka miliki. Dengan demikian, dalam perkembangan kehidupan keagamaan terkini, setiap pribadi perlu menyadari bahwa kehidupan sosial sudah terisi dengan kompleksitas peristiwa-peristiwa sosial kemasyarakatan dan sosial keagamaan. Sekarang ini, setiap orang dapat dipertemukan dengan perjumpaan antaragama dan budaya yang berbeda, sementara itu penghayatan agama pun semakin personal dan eksistensial. Setiap orang merasa bertanggungjawab atas agama yang dianutnya sendiri. Lebih lanjut, masyarakat dewasa ini dikondisikan oleh apa yang kini dikenal sebagai budaya global. Situasi ini mengisyaratkan bahwa dunia dan masyarakat umumnya menjadi semakin terbuka terhadap kemungkinan masuknya berbagai pemikiran dan keyakinan lain. ${ }^{39}$

Globalisasi yang telah merambah kehidupan sosial merupakan sebuah kenyataan yang harus direspon dengan kearifan demi menghidupkan kerukunan dalam keanekaragaman. Kehidupan sosial yang sangat terbuka luas bagi setiap individu akan menghantarkan mereka untuk menyadari bahwa keanekaragaman itu sendiri adalah hukum alam dalam hal ini merupakan sunnatullah untuk diimani oleh setiap manusia. Sementara itu, menjadikan keanekaragaman tersebut dalam satu bentuk adalah suatu kemustahilan dan hal itu bisa menimbulkan pengingkaran atas hukum alam yang ada. Mengutip firman Allah QS.

38Thohir, Multikulturalisme Agama, 42-3.

${ }^{39}$ Sudiarja, Agama di Zaman yang Berubah (Yogyakarta: Kanisius, 2006), 143. 
al-Maidah, [5]: 48, "Sekiranya Allah menghendaki, niscaya kamu dijadikan-Nya satu umat (saja), tetapi Allah hendak menguji kamu terhadap pemberian-Nya kepadamu, maka berlomba-lombalah berbuat kebajikan",40 hakikat keanekaragaman dalam hidup merupakan sunnatullāh yang sudah diciptakan. Bentang dunia yang sangat luas menjadi penanda kuat bahwa laju pertumbuhan manusia tidaklah menyatu dalam satu ciptaan yang sama. Mereka diciptakan dari perbedaan dalam segi etnis, suku bangsa, agama, dan golongan. Namun, di antara perbedaan yang ada, Tuhan menyiptakan ruang dialog bagi semua orang untuk berinteraksi dan bekerja sama. ${ }^{41}$

\section{Meneguhkan Nasionalisme}

Masyarakat Desa Pucakwangi sangat menjunjung tinggi kerukunan sosial di antara mereka. Anekaragam perbedaan yang terdapat di tengah-tengah masyarakat tidak menjadi penghalang bagi terciptanya kesetaraan. Masingmasing dari elemen masyarakat menyadari bahwa pencapaian kesejahteraan, kebahagiaan, dan ketentraman sosial akan tercipta dengan adanya sikap saling terbuka dan setara antara setiap individu di masyarakat. Keteguhan atas kondisi disampaikan oleh Haji Mukhlisin, Modin Desa Pucakwangi;

Masyarakat mriki sami guyup mas. Gotong royong dados pemandangan umum wonten tengah-tengah masyarakat (Masyarakat di sini sama-sama rukun Mas. Gotong-royong menjadi pemandangan umum yang bisa disaksikan di tengah-tengah mereka). ${ }^{42}$

Gambaran kerukunan yang terdapat di masyarakat Desa Pucakwangi menjadi ikonitas berharga bahwa kesatuan sikap dan kesamaan perasaan di lingkungan sosial menjadi modal utama guna meredam sikap-sikap radikal dalam beragama. Hal ini menjadi poin penting yang perlu digarisbawahi mengingat radikalisme agama merupakan fenomena yang tidak hanya berkembang pada komunitas tertentu. Namun eksistensinya sudah berkembang dalam bentuk yang bercorak transnasional. Hal itu dikarenakan hampir di seluruh negara terdapat fenomena radikalisme agama. Bahkan radikalisme

40Tim Penerjemah Yayasan Penerjemah al-Qur'an Depag RI, Al-Qur'an dan Terjemahnya (Semarang: Alwaah, 1993), 168.

41Thohir, Multikulturalisme Agama, 35-6.

42Wawancara dengan H. Mukhlisin, Modin Desa Pucakwangi, 15 Januari 2017. 
agama juga bercorak transreligius karena dialami oleh semua agama yang berkembang di dunia ini. Di mana dapat dikatakan fenomena ini telah berkembang dan berlangsung lama. ${ }^{43}$

Radikalisme dalam beragama menjadi ancaman atas harmoni sosial yang terbentuk di masyarakat. Sikap radikal dalam beragama dapat menjadi sebab terjadinya konflik-konflik horizontal. Mencegah terjadinya konflik dapat dilakukan dengan mengedepankan semangat pemahaman sosial atas harmoni bersama. Kondisi ini mutlak perwujudannya mengingat sikap radikal dapat menciptakan ketimpangan-ketimpangan dalam beragama. ${ }^{4}{ }^{4}$ Kondisi lain yang bisa disaksikan sebagai akibat radikalisme beragama adalah timbulnya ruangruang dan aktivitas sosial-keagamaan sebagai wilayah kontestasi bagi kelompok-kelompok radikal. Masjid-masjid di berbagai tempat menjadi lahan perebutan pengaruh antara kelompok-kelompok radikal dan moderat. 45 Kondisi ini memperparah situasi keanekaragaman sebagai model utama kehidupan keagamaan. Karenanya, sebagai pondasi penentangan atas radikalisme ini penting disikapi bersama bahwa hakikat agama sebagai pemersatu sosial. Eksistensi keanekaragaman sosial merupakan aset berharga yang bisa dijadikan pemicu bagi perwujudan integrasi dan harmoni sosial di masyarakat.

Semangat nasionalisme menjadi struktur kuat yang berfungsi mengikat masyarakat Desa Pucakwangi saling berinteraksi antara satu warga dengan warga lainnya. Kondisi ini tergambar dengan jelas pada kegiatan memperingati Hari Kemerdekaan Republik Indonesia. Warga saling bergotong-royong untuk meneguhkan semangat nasioalisme masing-masing.

Masyarakat bergotong royong pada saat bersih desa menyambut datangnya kegiatan Agustusan. Dalam acara Agustusan juga sering dilaksanakan lomba-lomba, dan semua warga ikut serta dalam kegiatan tersebut. 46

\footnotetext{
43Hasyim Muhammad, Khoirul Anwar, dan Misbah Zulfa Elizabeth, "Diskursus Deradikalisasi Agama: Pola Resistensi Pesantren terhadap Gerakan Radikal," Walisongo: Jurnal Penelitian Sosial Keagamaan 23, no. 1 (2015): 197-222, https://doi.org/10.21580/WS.23.1.230.

${ }^{44}$ Rahmini Hadi, "Pola Kerukunan Umat Beragama di Banyumas," Ibda: Jurnal Kajian Islam dan Budaya 14, no. 1 (2016): 65-78, https://doi.org/10.24090/IBDA.V14I1.560.

45Zakiyuddin Baidhawy, "Muatan Nilai-nilai Multikultural dan Antimultikultural dari Mimbar Masjid di Kota Solo," Analisa: Journal of Social Science and Religion 21, no. 2 (2014): 173-87, https://doi.org/10.18784/analisa.v21i02.13.

46Wawancara dengan Muhammad Ma'ruf, warga Desa Pucakwangi, 21 Januari 2018.
} 
Idealitas harmoni sosial menjadi cita-cita luhur yang selalu mengemuka di tengah pluralisme kehidupan masyarakat. Namun, harmoni sosial menjadi fakta pelik tatkala keberadaannya dipertemukan dengan perbincangan antara mayoritas dan minoritas. Kelompok mayoritas seringkali hadir mendominasi semua hal terkait dengan struktur-struktur sosial yang dibangun di tengah masyarakat. Ismail Suardi Wekke, ${ }^{47}$ Muzaki, ${ }^{48}$ I Gusti Ketut Arya Sunu, dkk., ${ }^{49}$ dan Biyanto ${ }^{50}$ menjelaskan harmoni sosial di tengah-tengah masyarakat minoritas berhubungan erat dengan upaya dan peran para tokoh agama, tokoh masyarakat, dan tokoh adat dalam rangka mengawasi dan menghidupkan harmonisasi sosial masyarakat yang plural. Nilai agama perlu dihadirkan sebagai pemersatu yang menyatukan berbagai kepentingan sosial di masyarakat. Menyadarkan atas semua nilai yang ada, peranan dari masing-masing tokoh agama, tokoh masyarakat, dan tokoh adat sangat berarti karena eksistensinya akan mewujudkan cita-cita bersama yang sudah dibangun dalam masingmasing agama.

Mencapai idealitas nilai dalam beragama keberadaannya terkait erat dengan konstruk pemahaman yang diperkenalkan dalam meyakini hakikat dasar agama. Para pemeluk agama memerlukan kesatuan sikap yang dibentuk dan dipersepsikan setara di antara masing-masing pemeluk agama. Konstruks keagamaan masing-masing pemeluk agama menjadi penting dimengerti sehingga jebakan-jebakan perbedaan yang ada menjadi terhindari. Dalam merumuskan perspektif mendasar keagamaan sebagai bagian pembahasan atas realitas perbedaannya di masyarakat, Ujang Mahadi, ${ }^{51}$ Casram, ${ }^{52}$ dan Brian

47Ismail Suardi Wekke, "Harmoni Sosial dalam Keberagaman dan Keberagamaan Masyarakat Minoritas Muslim Papua Barat,” Kalam 10, no. 2 (2016): 295-312, https://doi.org/10.24042/ klm.v10i2.3.

${ }^{48}$ Muzaki Muzaki, "Partisipasi Tokoh Masyarakat dalam Toleransi Umat Beragama," Komunika: Jurnal Dakwah dan Komunikasi 4, no. 2 (2018): 296-313, https://doi.org/10.24090/ komunika.v4i2.157.

49I Gusti Ketut Arya Sunu, "Harmonisasi, Integrasi Desa Pakraman Dengan Desa Dinas yang Multietnik dan Multiagama Menghadapi Pergeseran, Pelestarian, dan Konflik di Bali," Jurnal Ilmu Sosial dan Humaniora 3, no. 2 (2015): 446-58, https://doi.org/10.23887/jish-undiksha.v3i2.4469.

${ }^{50}$ Biyanto Biyanto, "Berdamai dengan Pluralitas Paham Keberagamaan," Teosofi: Jurnal Tasawuf dan Pemikiran Islam 5, no. 1 (2015): 164-89, https://doi.org/10.15642/teosofi. 2015.5.1.164-189.

51Ujang Mahadi, "Membangun Kerukunan Masyarakat Beda Agama melalui Interaksi dan Komunikasi Harmoni di Desa Talang Benuang Bengkulu," Jurnal Kajian Komunikasi 1, no. 1 (2013): 51-58, https://doi.org/10.24198/jkk.v1i1.6030. 
Leftow ${ }^{3}$ melihat bahwa kesadaran masing-masing pemeluk agama akan realitas perbedaan di antara mereka menjadi satu pijakan berharga guna menjadikan satu pemeluk agama dan pemeluk agama lainnya menyatu dalam perbedaanperbedaan yang ada.

Dinamika perbedaan dalam keberagamaan masyarakat juga tampak terlihat dalam ritus-ritus peribadatan. Ritual-ritual dalam peribadatan ini menjadi tampilan-tampilan lain yang bisa disaksikan dalam kepemelukan setiap pemeluk agama. Sebagai ekpsresi dari keyakinan atas agama yang dipeluknya tersebut, ritual-ritual yang ada perlu terus diwujudkan sebagai media para pemeluk agama untuk menuju Tuhan. Interrelasi agama dan ritus-ritus peribadatan menjadi sub bagian dari objektivikasi harmoni keberagamaan dalam dinamika keagamaan di masyarakat. Konsep dasar ini ditegaskan oleh Anne Pollok, ${ }^{54}$ Benjamin D. Crowe, ${ }^{55}$ Benjamin S. Cordry, ${ }^{56}$ dan Mikael Stenmark. ${ }^{57}$ Mereka melihat bahwa seremonial dalam agama merupakan sebuah bahasa yang akan dihadirkan dalam menjelaskan agama itu sendiri. Kehadiran agama dalam kehidupan masyarakat berperan pokok dalam rangka menumbuhkembangkan kehidupan dan mencapai kesempurnaan sosial.

Perbincangan mengenai pluralitas keagamaan menjadi satu titik pijak untuk menegaskan bahwa internal penganut agama memiliki kesamaan yang bersifat hegemonistik. Masing-masing agama terus membangun kesadaran kebersamaan di antara pemeluknya dan menjelaskan bahwa agama yang mereka yakini memiliki kontribusi besar atas tegak dan kokohnya keyakinan yang disepakati. Perspektif atas hal ini sebagaimana dikemukakan oleh Amir

\footnotetext{
${ }^{52}$ Casram Casram, "Membangun Sikap Toleransi Beragama dalam Masyarakat Plural," Wawasan: Jurnal Ilmiah Agama dan Sosial Budaya 1, no. 2 (2016): 187-98, https://doi.org/ 10.15575/jw.v1i2.588.

53Brian Leftow, "Swinburne on Divine Necessity," Religious Studies 46, no. 2 (2010): 141-62, https://doi.org/10.2307/25676934.

${ }^{54}$ Anne Pollok, "The Power of Rituals: Mendelssohn and Cassirer on the Religious Dimension of Bildung," Religious Studies 50, no. 4 (2014): 445-64, https://doi.org/10.1017/S0034412514000031.

${ }^{55}$ Benjamin D. Crowe, "Religion and the 'Sensitive Branch' of Human Nature," Religious Studies 46, no. 2 (2010): 251-63, https://doi.org/10.2307/25676940.

56Benjamin S. Cordry, "A Critique of Religious Fictionalism," Religious Studies 46, no. 1 (2010): 77-89, https://doi.org/10.1017/S0034412509990291.

57Mikael Stenmark, "Competing Conceptions of God: The Personal God versus the God beyond Being," Religious Studies 51, no. 2 (2015): 205-20, https://doi.org/10.1017/S0034412514000304.
} 
Tajdid,58 Muhammad Sholikhin ${ }^{59}$, Mujiburrahman, ${ }^{60}$ dan Akhmad Siddiq.61 Dalam pandangan mereka, timbulnya polemik dalam dinamika keberagamaan masyarakat disebabkan oleh ketidaksepahaman masyarakat kepada eksistensi pluralitas agama, dan kebenaran hegemonik yang akan terjadi di dalam bagian internal pemeluk agama.

\section{E. Interkorelasi Agama Pendahulu}

Pertumbuhan keyakinan di tengah-tengah masyarakat tidak dapat dijauhkan dari sistem-sistem kepercayaan yang berlangsung di masa-masa sebelumnya. Pola adaptasi menjadi suatu kondisi yang akan menjadikan manusia membentuk kesesuaian-kesesuain atas lingkungan baru yang mengitari. Langkah-langkah dari upaya ini diselenggarakan mulai dari pembentukan ideide, yaitu pola makna yang menjadi pedoman umum bagi perilaku berupa perangkat model-model pengetahuan, dan aktivitas sosial yakni kegiatan yang dilakukan bersama-sama oleh anggota masyarakat.62 Perwujudan sistem ini di kehidupan masyarakat sebagai sebuah reaksi atas makna agama sebagai kesatuan sistem kepercayaan dan praktik-praktik yang berkaitan dengan hal ihwal yang sakral, yaitu hal-hal yang disisihkan dan terlarang, kepercayaan dan praktik-praktik yang menyatukan seluruh orang yang menganut dan meyakini hal-hal tersebut ke dalam satu komunitas. ${ }^{63}$

Kesatuan perspektif keagamaan yang terdapat di masyarakat tidak dapat dijauhkan dari memori kolektif yang terdapat di tengah-tengah mereka. Secara teoritis Timothy Kubal menjelaskan bahwa kesatuan agama Kristen Protestan

${ }^{58}$ Amir Tajrid, "Kebenaran Hegemonik Agama," Walisongo: Jurnal Penelitian Sosial Keagamaan 20, no. 1 (30 Mei 2012): 193-210, https://doi.org/10.21580/ws.20.1.190.

${ }^{59}$ Muhammad Sholikhin, "Berbagai Masalah Keberagamaan Masyarakat Modern dalam Perspektif Dekonstruksi Dakwah Berbasis Psikologi Sosial," Komunika: Jurnal Dakwah dan Komunikasi 9, no. 1 (2015): 1-18, https://doi.org/10.24090/komunika.v9i1.827.

${ }^{60}$ Mujiburrahman, "Islam Multikultural: Hikmah, Tujuan, dan Keanekaragaman dalam Islam," Addin 7, no. 1 (2015): 65-80, https://doi.org/10.21043/addin.v7i1.570.

${ }^{61}$ Akhmad Siddiq, "Islamic Pluralism in Indonesia: Comparing Fundamentalist and Liberalist View," Teosofi: Jurnal Tasawuf dan Pemikiran Islam 1, no. 1 (2015): 131-41, https://doi.org/ 10.15642/teosofi.2011.1.1.131-141.

62Rusmin Tumanggor, Gerbang Agama-agama Nusantara: Hindu, Yahudi, Ru-Konghucu, Islam dan Nasrani (Kajian Antropologi Agama) (Jakarta: Komunitas Bambu, 2017), 4.

${ }^{63}$ Endraswara, Agama Jawa, 3. 
dan Katolik terbentuk kembali oleh memori kolektif yang diciptakan dalam pengembangan sosial internal mereka. Pengembangan ini bertitik pijak kepada kesepakatan untuk sama-sama mendidik masyarakat, berketuhanan, dan berpolitik. ${ }^{64}$ Asas teoitis ini pula yang teramati dengan kuat dalam sistem keagamaan yang tumbuh di antara kehidupan masyarakat Desa Pucakwangi. Kekuatan tradisi gotong-royong yang masih eksis di tengah-tengah mereka merupakan sebuah reaksi atas keyakinan-keyakinan pendahulunya.

Seguyup masyarakat sami terikat antawis setunggal warga kaleh sanesipun. Kegiatan-kegiatan niki sering kelaksanan nalika wonten kerja bakti, sesama warga saling tulung tinulung maringake unjuan kaleh daharan (Masyarakat saling terikat antara satu dengan lainnya. Kegiatan-kegiatan serupa ini seringkali terjalin di saat ada kerja bakti. Sesama warga saling tolongmenolong dengan memberikan minuman dan makanan). ${ }^{65}$

Terkait kekuatan sistem gotong-royong yang terdapat di kehidupan masyarakat tradisional, Koentjaraningrat menyatakan bahwa perwujudannya yang dihasilkan oleh masyarakat kota hanya menyentuh pada aspek produksi pertanian. Sementara itu, gotong-royong di masyarakat pedesaan lebih menyentuh pada gotong-royong formal antartetangga, gotong-royong dalam perayaanperayaan dan pesta, dan gotong-royong dalam bencana serta kematian. 66

Sistem kebudayaan yang dikaji melalui pola gotong-royong oleh Koentjaraningrat di atas memberikan titik pemisah bahwa realitas pertumbuhan desa dan kota memiliki aspek diferensiasi yang sangat berarti, "Desa mawa cara, negara mawa tata (desa memiliki adat kebiasaan, negara memiliki aturan hukum)" ${ }^{67}$ Perspektif ini menjelaskan realitas kebudayaan dalam sebuah sudut pandang bisa juga bertindak sebagai fungsi dari adaptasi karena kebudayaan lahir dalam rangka upaya menyesuaikan diri guna memecahkan masalahmasalah yang berkenaan dengan pemenuhan kebutuhan. Di sisi lain, karen adanya kapasitas manusia untuk berpikir secara metaforis. Hal tersebut diperlukan untuk memberikan dan menghubungkan berbagai makna dari simbol2008), 33.

64Timothy Kubal, Cultural Movements and Collective Memory (New York: Palgrave MacMillan,

65Wawancara dengan H. Mukhlisin, Modin Desa Pucakwangi, 15 Januari 2017.

66Koentjaraningrat, Sejarah Teori Antropologi II (Jakarta: UI Press, 2010), 6.

${ }^{67}$ Soetardjo Kartohadikoesoemo, Desa (Jakarta: Balai Pustaka, 1984), 114.

JURNAL THEOLOGIA — Volume 29, Nomor 2, Desember 2018 
simbol, lalu menggabungkan simbol-simbol tersebut ke dalam sistem makna yang mungkin berbeda atau berdiri sendiri dari makna aslinya. 68

Menganalisis dari sudut pandang genetis kebudayaan, dapat dipahami bahwa budaya lahir dari interaksi antar-manusia dan tetap bisa bertahan karena ditransmisikan dari satu generasi ke generasi berikutnya.69 Argumentasi ini menjelaskan bahwa dinamika kebudayaan yang ada di masa kini memiliki keterkaitan yang tidak bisa dihindari dari masa-masa lalu pendahulunya. Dinamika ini juga digambarkan secara utuh oleh Seyyed Hossein Nasr dalam menganalisis pertumbuhan Islam sebagai doktrin dan peradaban. Kaum Muslim dewasa ini terus bersentuhan dan mengalami kehadiran masyarakat agama lain di sekeliling mereka sebagaimana halnya yang terjadi selama berabad-abad yang lalu. Di tengah wilayah Islam terdapat minoritas-minoritas Kristen, yang jumlah terbesarnya ada di Mesir. Selain itu, masih juga didapati masyarakat Yahudi, terutama di Iran dan Turki, walaupun sebagian besar kaum Yahudi di negara-negara Arab telah berpindah ke Israel sejak 1948. Penganut Zoroaster masih dijumpai di Iran dan kaum Muslim hidup berdampingan dengan panganut agama Hindu, yang tidak hanya terlihat di India, tetapi juga di Bangladesh, Nepal, Malaysia, dan Indonesia dan dengan masyarakat Buddha di Sri Lanka, Thailand, Ladakh, Burma, Cina, dan di negara-negara lain. Begitu juga masyarakat Muslim hidup berdampingan dengan penganut Konfusianisme dan Taoisme, tidak cuma di Cina, tetapi juga di Malaysia dan Indonesia. Secara umum, dapat dikatakan bahwa sepanjang sejarah Islam, hubungan antara masyarakat Muslim dan kaum minoritas yang ada di negara atau wilayah mereka berlangsung baik dan harmonis. ${ }^{70}$

Perjumpaan agama Islam dengan agama-agama lain yang ada di sekitarnya meneguhkan secara alamiah bahwa keberadaan agama ini akan selalu berinteraksi dengan agama-agama lain di sekitarnya. Dalam kondisi ini, agamaagama tersebut secara alamiah dipertemukan dengan beragam situasi guna saling bekerja sama. Sementara itu, di antara syarat untuk bisa bekerja sama adalah keterciptaan kondisi saling: mengenal, menghormati, menerima, dan

68Tumanggor, Gerbang Agama-agama Nusantara, 4-5. 2005), 9.

${ }^{69}$ Mudji Sutrisno dan Hendar Putranto, ed., Teori-teori Kebudayaan (Yogyakarta: Kanisisus,

70Seyyed Hossein Nasr, The Heart of Islam: Pesan-pesan Universal Islam untuk Kemanusiaan, ed. Nurasiah Fakih Sutan Harahap (Bandung: Mizan, 2003), 56-7. 
memberi ruang dalam kerangka pemenuhan kebutuhan hidup manusia sebagai makhluk sosial secara bermartabat. ${ }^{71}$

Pada bagian yang lain, dinamika perjumpaan agama-agama merupakan keniscayaan yang perlu disadari oleh masing-masing pemeluk agama. Perbedaan yang terjadi tiada lain sebagai sebuah bentuk dinamika itu sendiri. Untuk alasan inilah, penting menyandarkan analisis agama pada nalar kebudayaan. Agama sebagai bagian dari kebudayaan adalah agama yang dipahami, dihayati, dan dipraktikkan oleh manusia-manusia historis dan karena itu ia menjadi bagian dari objek kajian ilmiah. Termasuk dalam hal ini adalah produk-produk yang dihasilkan oleh aktor-aktor agama seperti teks atau aktivitas-aktivitas keagamaan seperti lembaga agama dan semacamnya. Segala produk pemikiran dan aktivitas keagamaan biasanya berkelindan erat dengan aktivitas politik, ekonomi, budaya, dan kehidupan sosial yang semakin menguatkan agama sebagai objek kajian ilmiah. ${ }^{72}$

Berbagai bentuk dinamika perjumpaan agama-agama yang bertumbuhkembang dalam keanekaragamannya, hal tersebut hanya menjadi titik pemicu yang bisa dimunculkan guna menegaskan bahwa realitas kebenaran dalam agama merupakan bagian yang bisa dijumpai di internal agama-agama. Sebagai dasar analisis atas hal ini, Paul F. Knitter mencoba mendeskripsikan dari Dialogue and Proclamation (DP), yang diterbitkan bersama oleh Komisi Dialog Antar-agama dan Kongregasi bagi Pemberitaan Bangsa-Bangsa tahun 1991, bahwa para juru bicara Gereja Katolik secara eksplisit mengakui kehadiran aktif Allah melalui firman-Nya dan kehadiran Roh yang universal, bukan hanya di dalam individu di luar gereja tetapi juga di dalam agama-agama mereka. Dialogue and Proclamation (DP) menyimpulkan bahwa agama-agama dunia memainkan peran providensial di dalam ekonomi keselamatan ilahi. Menyikapi positif ekonomi ilahi-ini bahasa teologis untuk mengatakan bahwa di dalam dan melalui agama-agama lain, manusia benar-benar dapat menemukan dan berhubungan dengan Allah. ${ }^{73}$

71Thohir, Multikulturalisme Agama, 36.

72Media Zainul Bahri, Wajah Studi Agama-agama dari Era Teosofi Indonesia (1901-1940) hingga Masa Reformasi (Yogyakarta: Pustaka Pelajar, 2015), 15.

73Paul F. Knitter, Pengantar Teologi Agama-agama (Yogyakarta: Kanisius, 2014), 97. 
Pertemuan satu individu dengan individu lain dalam rangka meneguhkan eksistensi harmoni dalam keanekaragaman menjadi konsep fundamental yang dibangun di dalam kehidupan agama-agama. Jack David Eller menegaskan di antara agama-agama terdapat kesamaan perspektif yang tidak bisa dibantah bahwa alam semesta terbentuk dalam rangka meneguhkan humanitas. Alam kosmologi diciptakan dalam sebuah struktur untuk meneguhkan absolusitas Tuhan. Terminologi ini dimunculkan sebagai sebuah asas fundamental berpikir untuk menyatukan kesadaran prinsip dasar penciptaan mengantisipasi pertentangan-pertentangan yang terjadi di antara agama-agama. Adapun keanekaragaman yang terjadi di antara mereka adalah perspektif tentang perbedaan penyebutan istilah-istilah ketuhanan di tengah-tengah para pemeluk agama. $^{74}$

Peranan demi peranan yang dimunculkan oleh agama untuk kemanusiaan tidaklah bisa dianggap minus. Agama mengambil bagian pada saat-saat yang paling penting dan pada pengalaman-pengalaman hidup. Agama merayakan kelahiran, menandai pergantian jenjang masa dewasa, mengesahkan perkawinan serta kehidupan keluarga, dan melapangkan jalan dari kehidupan kini menuju ke kehidupan yang akan datang. Bagi berjuta-juta manusia, agama berada dalam kehidupan mereka pada saat-saat yang paling khusus maupun pada saat-saat yang peling mengerikan. Agama juga memberikan jawabanjawaban terhadap pertanyaan-pertanyaan yang membingungkan banyak umat manusia. ${ }^{75}$

Kesatuan perspektif dalam keanekaragaman agama yang berjalan di antara para penganut agama meneguhkan bahwa mereka memiliki kecenderungan yang sama dalam rangka mewujudkan kesadaran pengetahuan mereka akan Tuhan. Sebagai Pencipta alam semesta, para penganut agama-agama meyakini secara seksama akan adanya kekuatan yang absolut atas kehidupan mereka. Menegaskan perspektifini, Brian Morris mencatat:

"Agama sebagai bentuk paling awal dan tidak langsung dari pengetahuan diri manusia. Mula-mula manusia melihat sifatnya seolah-olah di luar dirinya sebelum dia menekannya dalam dirinya sendiri. Sifat kediriannya, mula-mula direnungkannya sendiri sebagai sesuatu yang lain. Agama

${ }^{74}$ Jack David Eller, Introducing Anthropology of Religion (New York: Routledge, 2007), 44-5.

${ }^{75}$ Michael Keene, Agama-agama Dunia, terj. F. A. Soeprapto (Yogyakarta: Kanisius, 2014), 6. 
adalah kondisi manusia yang kekanak-kanakan; tetapi anak itu melihat sifatnya di luar dirinya sendiri. 'Ada' ketuhanan yang tidak lain dari manusia itu sendiri, atau lebih tepatnya murni tabiat manusia, terbebas dari batasanbatasan individu manusia, membuat tujuan-tujuan-yakni direnungkan dan dipuja sebagai yang lain, sebagai 'ada' yang khas." ${ }^{\text {"6 }}$

Meneguhkan perspektif ketuhanan dalam diri setiap pemeluk agama, hal tersebut menandaskan secara konseptual bahwa agama-agama yang berjalan memiliki kesatuan pemahaman atas prinsip-prinsip dasar ketuhanan. Ketuhanan dalam agama-agama memiliki dasar pemahaman yang sama karena keberadaannya membincang hal tersuci "The Sacred" dalam titik intrinsik agama-agama. Titik-titik kesucian dalam agama pada intinya hadir sebagai sumber nilai-nilai humanitas di tengah evolusi yang berkembang di dunia. ${ }^{77}$ Humanitas dalam kehidupan sosial menjadi satu aspek mendasar yang meneguhkan fakta dari aneka ragam kehidupan sebagai pijakan dasar dari pertumbuhan sosial di tengah-tengah kehidupan manusia.

Manusia akan dipertemukan dengan sikap-sikap korelasional atas beragam peristiwa yang dihadapi dan dijumpai. Senada dengan kerangka ini Adelbert Snijders ${ }^{78}$ menjelaskan bahwa sikap dinamis yang dimiliki oleh manusia disandarkan kepada kenyataan dirinya yang senantiasa berjalan menuju kebenaran dan tidak berhenti. Manusia tidak pernah tamat dan tidak pernah sampai pada titik selesai. Dinamika agama dan keberagamaan dalam kehidupan sosial merupakan keberadaan yang akan selalu dijumpai.

\section{F. Kesimpulan}

Menelisik kerukunan dalam keanekaragaman di kehidupan masyarakat Desa Pucakwangi Kecamatan Pucakwangi Kabupaten Pati Jawa Tengah, tampak kehidupan mereka dimulai dari friksionalitas hubungan agama dan kecenderungan ideologi. Namun, semua kondisi tersebut melebur dalam kondisi masyarakat Desa Pucakwangi terkini dengan terbentuknya kesadaran terhadap

76Brian Morris, Antropologi Agama: Kritik Teori Agama Kontemporer, terj. Imam Khoiri (Yogyakarta: AK Group, 2003), 21.

${ }^{77}$ Roy A. Rappaport, Ritual and Religion in the Making of Humanity (Cambridge: Cambridge University Press, 1999), 1.

${ }^{78}$ Adelbert Snijders, Manusia dan Kebenaran (Yogyakarta: Kanisius, 2006), 4. 
kesamaan dasar keyakinan di antara mereka. Kesamaan rasa dalam keberagamaan masyarakat ini tercurah dengan derasnya pada partisipasi mereka di kegiatan-kegiatan sosial lintas agama. Acara tahlilan ketika seorang Muslim meninggal dunia, kaum Nasrani juga ikut serta memberikan penghormatan.

Ciri nasionalisme tampak terlihat dalam kehidupan masyarakat Desa Pucakwangi. Kegiatan gotong-royong dalam rangka menyambut Peringatan Hari Kemerdekaan Republik Indonesia, hal tersebut dilakukan dengan keikutsertaan semua warga dari semua latarbelakang agama. Secara otomatis pula, masyarakat terlibat saling membantu dalam acara-acara kerja bakti sebagaimana hal ini juga mereka lakukan di kegiatan-kegiatan cocok tanam, utamanya tanam padi.

Solidaritas para pemeluk beda agama di Desa Pucakwangi terbentuk dengan kuat dengan kesadaran terhadap interkorelasi sesamanya dalam kehidupan sosial. Bertitik pijak pada teori memori kolektif yang dibangun oleh Timothy Kubal terlihat jelas bahwa masyarakat Desa Pucakwangi meyakini keberadaan mereka terkini adalah adanya hubungan sosial yang telah terbangun di masa-masa lampau oleh para pendahulunya. Perayaan hari-hari besar agama, menjadi salah satu metode untuk meneguhkan kesatuan budaya mereka yang menyatu dari leluhur yang sama.]

\section{DAFTAR PUSTAKA}

Abdillah, Mujiyono. Islam Dialektik: Varitas Islam Terkini. Semarang: al-Hikmah, 2013.

Abdullah, Irwan. Konstruksi dan Reproduksi Kebudayaan. Yogyakarta: Pustaka Pelajar, 2015.

Abdullah, M. Amin. "An Analytical Perspective in the Study of Religious Diversity: Searching for a New Model of the Philosophy of the Study of Religions." dalam Religious Harmony, ed. Michael Pye. Berlin: Walter de Gruyter, 2006.

Aziz, Munawir. “Identitas Kaum Samin Pasca Kolonia Pergulatan Negara, Agama, dan Adat dalam Pro-Kontra Pembangunan Pabrik Semen di Sukolilo, Pati, 
Jawa Tengah." Jurnal Kawistara 2, no. 3 (2012): 252-63. https://doi.org/ 10.22146/KAWISTARA.3937.

Bahri, Media Zainul. Wajah Studi Agama-agama dari Era Teosofi Indonesia (19011940) hingga Masa Reformasi. Yogyakarta: Pustaka Pelajar, 2015.

Baidhawy, Zakiyuddin. "Muatan Nilai-nilai Multikultural dan Antimultikultural dari Mimbar Masjid di Kota Solo." Analisa: Journal of Social Science and Religion 21, no. 2 (2014): 173-87. https://doi.org/10.18784/ analisa.v21i02.13.

Biyanto, Biyanto. "Berdamai dengan Pluralitas Paham Keberagamaan." Teosofi: Jurnal Tasawuf dan Pemikiran Islam 5, no. 1 (2015): 164-89. https://doi.org/10.15642/teosofi.2015.5.1.164-189.

Burke, Peter. Sejarah dan Teori Sosial. Jakarta: Yayasan Pustaka Obor Indonesia, 2015.

Casram. "Membangun Sikap Toleransi Beragama dalam Masyarakat Plural." Wawasan: Jurnal Ilmiah Agama dan Sosial Budaya 1, no. 2 (2016): 187-98. https://doi.org/10.15575/jw.v1i2.588.

Castles, Lance. Tingkah Laku Agama, Politik dan Ekonomi di Jawa: Industri Rokok di Kudus. Ed. J. Sirait. Jakarta: Sinar Harapan, 1982.

Cordry, Benjamin S. "A Critique of Religious Fictionalism." Religious Studies 46, no. 1 (2010): 77-89. https://doi.org/10.1017/S0034412509990291.

Crowe, Benjamin D. "Religion and the 'Sensitive Branch' of Human Nature." Religious Studies 46, no. 2 (2010): 251-63. https://doi.org/10.2307/ 25676940.

Eller, Jack David. Introducing Anthropology of Religion. New York: Routledge, 2007.

Endraswara, Suwardi. Agama Jawa: Ajaran, Amalan, dan Asal-usul Kejawen. Yogyakarta: Narasi, 2015.

Galtung, Johan. Peace by Peaceful Means Peace and Conflict, Development and Civilization. London: Sage Publications, 1996.

Hadi, Rahmini. "Pola Kerukunan Umat Beragama di Banyumas." Ibda: Jurnal Kajian Islam dan Budaya 14, no. 1 (2016): 65-78. https://doi.org/ 10.24090/IBDA.V14I1.560. 
Harahap, Syahrin. Teologi Kerukunan. Jakarta: Prenadamedia Group, 2011.

Jones, Pip. Pengantar Teori-teori Sosial dari Teori Fungsionalisme hingga PostModernisme. Ed. Ahmad Fedyani Saifuddin. Jakarta: Yayasan Obor Indonesia, 2009.

Kartohadikoesoemo, Soetardjo. Desa. Jakarta: Balai Pustaka, 1984.

Keene, Michael. Agama-agama Dunia. Ed. F. A. Soeprapto. Yogyakarta: Kanisius, 2014.

Ketut Arya Sunu, I Gusti. "Harmonisasi, Integrasi Desa Pakraman dengan Desa Dinas yang Multietnik dan Multiagama Menghadapi Pergeseran, Pelestarian, dan Konflik di Bali." Jurnal Ilmu Sosial dan Humaniora 3, no. 2 (2015): 446-58. https://doi.org/10.23887/jish-undiksha.v3i2.4469.

Knitter, Paul F. Pengantar Teologi Agama-agama. Yogyakarta: Kanisius, 2014.

Koentjaraningrat. Pengantar Antropologi II: Pokok-Pokok Etnografi. Jakarta: Rineka Cipta, 2005.

-_- Sejarah Teori Antropologi I.Jakarta: UI-Press, 2007.

-_- Sejarah Teori Antropologi II.Jakarta: UI Press, 2010.

Kubal, Timothy. Cultural Movements and Collective Memory. New York: Palgrave Macmillan, 2008.

Leftow, Brian. "Swinburne on Divine Necessity." Religious Studies 46, no. 2 (2010): 141-62. https://doi.org/10.2307/25676934.

Ludji, Irene, dan Mariska Lauterboom. "Learning from the Socio-Religious Integration in Solor Village Indonesia." Analisa: Journal of Social Science and Religion 22, no. 1 (2015): 43-56. https://doi.org/10.18784/ analisa.v22i1.145.

Mahadi, Ujang. "Membangun Kerukunan Masyarakat Beda Agama melalui Interaksi dan Komunikasi Harmoni di Desa Talang Benuang Bengkulu." Jurnal Kajian Komunikasi 1, no. 1 (2013): 51-58. https://doi.org/ 10.24198/jkk.v1i1.6030.

Martono, Nanang. Sosiologi Perubahan Sosial Perspektif Klasik, Modern, Posmodern, dan Poskolonial. Jakarta: Rajawali Pers, 2014.

Marzali, Amri.Antropologi dan Pembangunan.Jakarta: Kencana, 2015. 
Morris, Brian. Antropologi Agama: Kritik Teori Agama Kontemporer. Ed. Imam Khoiri. Yogyakarta: AK Group, 2003.

Muhammad, Hasyim, Khoirul Anwar, and Misbah Zulfa Elizabeth. "Diskursus Deradikalisasi Agama: Pola Resistensi Pesantren terhadap Gerakan Radikal." Walisongo: Jurnal Penelitian Sosial Keagamaan 23, no. 1 (2015): 197-222. https://doi.org/10.21580/WS.23.1.230.

Mujiburrahman. "Islam Multikultural: Hikmah, Tujuan, dan Keanekaragaman dalam Islam." Addin 7, no. 1 (2015): 65-80. https://doi.org/10.21043/ addin.v7i1.570.

Muzaki. "Partisipasi Tokoh Masyarakat dalam Toleransi Umat Beragama." Komunika: Jurnal Dakwah dan Komunikasi 4, no. 2 (2018): 296-313. https://doi.org/10.24090/komunika.v4i2.157.

Nasr, Seyyed Hossein. The Heart of Islam: Pesan-pesan Universal Islam untuk Kemanusiaan. Ed. Nurasiah Fakih Sutan Harahap. Bandung: Mizan, 2003.

Northcutt, Wendy. The Darwin Awards Survival of the Fittest. New York: The Dutton Publishing Group, 2001.

Plummer, Ken. Sociology The Basic. Terj. Nanang Martono and Sisworo. Jakarta: Rajawali Press, 2013.

Pollok, Anne. "The Power of Rituals: Mendelssohn and Cassirer on the Religious Dimension of Bildung." Religious Studies 50, no. 4 (2014): 445-64. https://doi.org/10.1017/S0034412514000031.

Pranowo, Bambang. Memahami Islam Jawa. Jakarta: Pustaka Alvabet, 2011.

Rappaport, Roy A. Ritual and Religion in the Making of Humanity. Cambridge: Cambridge University Press, 1999.

Ricklefs, Merle Calvin. Sejarah Indonesia Modern 1200-2004. Terj. Satrio Wahono. Jakarta: Serambi Ilmu Semesta, 2005.

Sholikhin, Muhammad. "Berbagai Masalah Keberagamaan Masyarakat Modern dalam Perspektif Dekonstruksi Dakwah Berbasis Psikologi Sosial." Komunika: Jurnal Dakwah dan Komunikasi 9, no. 1 (2015): 1-18. https://doi.org/10.24090/komunika.v9i1.827.

Siddiq, Akhmad. "Islamic Pluralism in Indonesia: Comparing Fundamentalist and Liberalist View." Teosofi: Jurnal Tasawuf Dan Pemikiran Islam 1, no. 1 (2015): 131-41. https://doi.org/10.15642/teosofi.2011.1.1.131-141. 
Snijders, Adelbert. Manusia dan Kebenaran. Yogyakarta: Kanisius, 2006.

Spencer, Herbert. First Principles. New York: Cambridge University Press, 2009.

Stenmark, Mikael. "Competing Conceptions of God: The Personal God versus the God beyond Being." Religious Studies 51, no. 2 (2015): 205-20. https://doi.org/10.1017/S0034412514000304.

Sudiarja. Agama di Zaman yang Berubah. Yogyakarta: Kanisius, 2006.

Suharko. "Karst: Ditambang atau Dilestarikan, Konflik Sosial Rencana Pembangunan Pabrik Semen di Kabupaten Pati Jawa Tengah." Jurnal Ilmu Sosial dan Ilmu Politik 17, no. 2 (2013): 163-79. https://doi.org/ 10.22146/JSP.10881.

Sutrisno, Mudji, and Hendar Putranto, eds. Teori-teori Kebudayaan. Yogyakarta: Kanisisus, 2005.

Syam, Nur. Madzhab-madzhab Antropologi. Yogyakarta: LKiiS, 2012.

Tajrid, Amir. "Kebenaran Hegemonik Agama." Walisongo: Jurnal Penelitian Sosial Keagamaan 20, no. 1 (2012): 193-210. https://doi.org/10.21580/ ws.20.1.190.

Thohir, Mudjahirin. Kekerasan Sosial di Pesisir Utara Jawa. Semarang: Lengkong Cilik Press, 2005.

-_- Multikulturalisme Agama, Budaya, dan Sastra. Semarang: Gigih Pustaka Mandiri, 2013.

Tim Penerjemah Yayasan Penerjemah al-Qur'an Depag RI. Al-Qur'an dan Terjemahnya. Semarang: Alwaah, 1993.

Tumanggor, Rusmin. Gerbang Agama-agama Nusantara: Hindu, Yahudi, RuKonghucu, Islam dan Nasrani (Kajian Antropologi Agama). Jakarta: Komunitas Bambu, 2017.

Wekke, Ismail Suardi. "Harmoni Sosial dalam Keberagaman dan Keberagamaan Masyarakat Minoritas Muslim Papua Barat." Kalam 10, no. 2 (2016): 295312. https://doi.org/10.24042/klm.v10i2.3. 